\title{
Blood Rheology, Cardiovascular Risk Factors, and Cardiovascular Disease: The West of Scotland Coronary Prevention Study
}

\author{
Gordon Lowe', Ann Rumley' John Norrie'2, lan Ford², James Shepherd 3 , \\ Stuart Cobbe 4 , Peter Macfarlane ${ }^{4}$, Christopher Packard ${ }^{3}$ \\ on behalf of the West of Scotland Coronary Prevention Study Group*
}

From the Departments of ${ }^{~} M e d i c i n e,{ }^{2}$ Biostatistics, ${ }^{3}$ Clinical Biochemistry, and ${ }^{4}$ Medical Cardiology, University of Glasgow, Glasgow, UK

\section{Key words}

Rheology, viscosity, coronary heart disease, lipoproteins, pravastatin

\section{Summary}

The West of Scotland Coronary Prevention Study (WOSCOPS) showed that pravastatin reduced the risk of coronary heart disease (CHD) events in 6,595 middle-aged hypercholesterolaemic men aged 45-64 years without prior myocardial infarction followed for an average of 4.9 years. We hypothesised prospectively (a) that baseline levels of haemorheological variables were related to baseline and incident CHD and to mortality; and (b) that reduction in lipoproteins by pravastatin would lower plasma and blood viscosity, a potential contributory mechanism to CHD events. We therefore studied plasma and blood viscosity, fibrinogen, haematocrit, and blood cell counts at baseline and 1 year. At baseline, plasma and blood viscosity were related to risk factors, CHD measures, and claudication. On univariate analysis, baseline levels of all rheological variables (except platelet count) were related to incident CHD; CHD mortality; and total mortality. On multivariate analysis including baseline $\mathrm{CHD}$ and risk factors, plasma and blood viscosity, haematocrit and white cell count each remained significantly associated with incident CHD; while fibrinogen remained an independent predictor of mortality (all $\mathrm{p}<0.03$ ). After one year, lipoprotein reduction by pravastatin was associated with significant reductions (about one quarter of a standard deviation) in plasma viscosity (mean difference $0.02 \mathrm{mPa} . \mathrm{s}, \mathrm{p}<0.001$ ) and in blood viscosity (mean difference $0.06 \mathrm{mPa} . \mathrm{s}, \mathrm{p}<0.001$ ), but was not associated with significant changes in other rheological variables. We therefore suggest that pravastatin therapy, which reduces elevated lipoproteins in hypercholesterolaemic men, may lower risks of CHD and mortality partly by lowering plasma and blood viscosity. Further studies are required to test this hypothesis.

Correspondence to: Prof. Gordon D. O. Lowe, University Department of Medicine, Royal Infirmary, 10 Alexandra Parade, Glasgow G31 2ER, UK Tel: +44 141211 5412; Fax: +44 141211 0414; E-mail: gdl1j@clinmed.gla.ac. uk

* Members of the West of Scotland Coronary Prevention Study Group: J. Shepherd, S. Cobbe, I. Ford, C. Packard, P. Macfarlane, A. R. Lorimer, J. H. McKillop and C. G. Isles

\section{Introduction}

The West of Scotland Coronary Prevention Study (WOSCOPS) recently showed that treatment with pravastatin in moderately hypercholesterolaemic men reduced the relative risk of coronary heart disease (CHD; first myocardial infarction or fatal CHD) by $31 \%$ (1). While the proportional benefit was independent of other $\mathrm{CHD}$ risk factors, the absolute benefit was greatest in subjects with the highest baseline risk (2). These results are consistent with other trials of cholesterol and low density lipoprotein (LDL) reduction, and with the relationships between cholesterol, LDL and CHD in epidemiological and observational studies (3). The causal roles of cholesterol and LDL in CHD appear partly due to their associations with coronary atherosclerosis, as shown by necropsy and angiographic correlations and by angiographic studies of cholesterol reduction (3). However, it seems unlikely that changes in coronary atherosclerosis during cholesterol reduction are sufficient to explain the early reduction in CHD events $(3,4)$.

Other mechanisms by which reductions in LDL and cholesterol might reduce the risk of CHD events include reductions in activation and rupture of arterial plaques and in superadded thrombosis; reduction in endothelial dysfunction; and reduction in plasma and blood viscosity, the major rheological determinants of blood flow (3-6). LDL and VLDL cholesterol are determinants of plasma and blood viscosity (5, 7-11) which in turn are related to risk of CHD in prospective epidemiological studies $(10,12,13,14)$. The predictive value of plasma viscosity for $\mathrm{CHD}$ is partly related to the effects of fibrinogen as well as lipoproteins $(5,10,12,13)$.

At the start of this study, we hypothesised (a) that baseline levels of rheological variables were associated with baseline and incident CHD and mortality (5), and (b) that pravastatin therapy, by reducing plasma lipoproteins, would lower plasma and blood viscosity. We therefore measured viscosity, fibrinogen, and blood cell counts at baseline and 1 year; and now report their relationships to cardiovascular risk factors, baseline and incident CHD, mortality, and pravastatin treatment.

\section{Subjects and Methods}

These have been described previously $(1,2,15,16)$. Briefly, the West of Scotland Coronary Prevention Study randomised 6,595 men aged 45-64 years with LDL levels of $4.96 \pm 0.44 \mathrm{mmol} / \mathrm{L}$ after dietary advice, to receive pravastatin $40 \mathrm{mg}$ each evening or placebo. The average follow-up period was 4.9 years. Self-reported hypertension, diabetes, CHD, claudication, medication, smoking habit, alcohol consumption and employment status were documented and seated blood pressure measured. Baseline lipoprotein levels were determi- 
Table 1 Distributions of rheological variables and relationships to smoking habit. Data are given as mean (SD)

\begin{tabular}{|c|c|c|c|c|}
\hline Smoking Habit & $\begin{array}{c}\text { Total } \\
(n=6595)\end{array}$ & $\begin{array}{c}\text { Never } \\
(n=1423)\end{array}$ & $\begin{array}{c}\mathbf{E x} \\
(n=2265)\end{array}$ & $\begin{array}{c}\text { Current } \\
(n=2907)\end{array}$ \\
\hline $\begin{array}{l}\text { Fibrinogen (FIB) } \\
(\mathrm{g} / \mathrm{L})\end{array}$ & $\begin{array}{c}4.30 \\
(0.86)\end{array}$ & $\begin{array}{c}4.06 \\
(0.80)\end{array}$ & $\begin{array}{c}4.15 \\
(0.82)\end{array}$ & $\begin{array}{c}4.52 \\
(0.87)\end{array}$ \\
\hline $\begin{array}{l}\text { Plasma viscosity (PV) } \\
\text { (mPa.s) }\end{array}$ & $\begin{array}{c}1.330 \\
(0.081)\end{array}$ & $\begin{array}{c}1.318 \\
(0.076)\end{array}$ & $\begin{array}{l}1.327 \\
(0.080)\end{array}$ & $\begin{array}{c}1.339 \\
(0.084)\end{array}$ \\
\hline $\begin{array}{l}\text { Blood viscosity (BV) } \\
\text { (mPa.s) }\end{array}$ & $\begin{array}{c}3.39 \\
(0.29)\end{array}$ & $\begin{array}{c}3.32 \\
(0.26)\end{array}$ & $\begin{array}{c}3.34 \\
(0.26)\end{array}$ & $\begin{array}{l}3.46 \\
(0.30)\end{array}$ \\
\hline $\begin{array}{l}\text { Haematocrit (HCT) } \\
(\%)\end{array}$ & $\begin{array}{l}43.9 \\
(2.9)\end{array}$ & $\begin{array}{l}43.4 \\
(2.7)\end{array}$ & $\begin{array}{l}43.3 \\
(2.7)\end{array}$ & $\begin{array}{l}44.6 \\
(3.0)\end{array}$ \\
\hline $\begin{array}{l}\text { Mean cell volume (MCV) } \\
\text { (fL) }\end{array}$ & $\begin{array}{l}90.8 \\
(4.1)\end{array}$ & $\begin{array}{l}89.5 \\
(3.8)\end{array}$ & $\begin{array}{l}90.1 \\
(3.9)\end{array}$ & $\begin{array}{l}91.9 \\
(4.1)\end{array}$ \\
\hline $\begin{array}{l}\text { Red cell count (RCC) } \\
\left(10^{12} / \mathrm{L}\right)\end{array}$ & $\begin{array}{c}4.85 \\
(0.34)\end{array}$ & $\begin{array}{c}4.85 \\
(0.34)\end{array}$ & $\begin{array}{c}4.82 \\
(0.34)\end{array}$ & $\begin{array}{c}4.87 \\
(0.35)\end{array}$ \\
\hline $\begin{array}{l}\text { White cell count (WCC) } \\
\left(10^{9} / \mathrm{L}\right)\end{array}$ & $\begin{array}{c}6.57 \\
(1.85)\end{array}$ & $\begin{array}{c}5.57 \\
(1.24)\end{array}$ & $\begin{array}{c}5.94 \\
(1.40)\end{array}$ & $\begin{array}{c}7.55 \\
(1.94)\end{array}$ \\
\hline $\begin{array}{l}\text { Platelet count (PC) } \\
\left(10^{9} / \mathrm{L}\right)\end{array}$ & $\begin{array}{l}284 \\
(65)\end{array}$ & $\begin{array}{l}275 \\
(62)\end{array}$ & $\begin{array}{l}283 \\
(64)\end{array}$ & $\begin{array}{l}290 \\
(68)\end{array}$ \\
\hline
\end{tabular}

ned from the mean of two fasting analyses performed at the second and third screening visits at least 4 weeks apart following a minimum of 4 weeks dietary advice.

At the third visit, a fasting venous blood sample was also anticoagulated with $\mathrm{K}_{2}$ EDTA (1.5 mg/mL) for measurement of rheological variables. Plasma viscosity was measured in a Coulter semi-automated capillary viscometer at $37^{\circ} \mathrm{C}$ (13). Plasma fibrinogen was assayed by heat precipitation nephelometry $(10,12,17,18)$. Blood counts were performed on Coulter STKR or $S+1$ automated cell counters. High-shear whole-blood viscosity was calculated from plasma viscosity and haematocrit according to the equation of Whittington and Harkness (19) from data previously collected from West of Scotland men aged 45-64 years in the Scottish Heart Health Study/Glasgow MONICA Study (8). These measurements (except platelet count) were repeated at the 1 year study visit.

Statistical analyses were performed on all available data. Continuous variables were summarised by mean and SD. Spearman rank correlations between continuous variables were calculated. For comparisons of mean levels of continuous variables, 2-sample t-tests were used for unpaired data and paired t-tests for paired data. Univariate hazard ratios (for changes approximating 1 SD for each variable) were calculated from Cox proportional hazards models (20) relating rheological variables to three major study endpoints (definite non-fatal
MI or CHD death: the primary study endpoint; CHD death; and all-cause mortality). Corresponding multivariate hazard ratios for selected rheological variables were calculated after adjusting for a hierarchy of baseline covariates relevant to CHD risk: (1) age and treatment group (pravastatin/placebo); (2) + current tobacco-smoking (yes/no); (3) + lipids (HDL, LDL and VLDL cholesterol; log triglyceride); (4) + other risk factor covariates: height, weight, body mass index, systolic and diastolic blood pressures, alcohol (units/week), diabetes (yes/no), hypertension (yes/no), school leaving certificate or better (yes/no), widowhood (yes/no) and current employment (yes/no); (5) + CHD indicators: nitrate use (yes/no), minor ECG abnormality (any of Minnesota Codes 4-2, $4-3,5-2,5-3$ : yes/no), positive Rose angina or intermittent claudication questionnaire (yes/no), or family history of premature CHD (yes/no). All p-values from the Cox models are for the Wald statistic.

\section{Results}

Table 1 shows the baseline distributions of rheological variables as well as their relationships to smoking habit. All rheological variables were related to smoking habit (overall $\mathrm{F}$ tests, $\mathrm{P}<0.0001$ ). Plasma viscosity, fibrinogen, mean red cell volume, white cell count and platelet count were all significantly higher in current smokers than in former smokers, who in turn had significantly higher levels than in men who had never smoked. Blood viscosity, haematocrit and red cell count were significantly higher in current smokers than ex-smokers, whose levels were not significantly different from men who had never smoked, apart from having a lower red cell count. Significant correlations were observed between fibrinogen and plasma viscosity (Spearman $r=0.47$ ), white cell count $(r=0.33)$ and blood viscosity $(r=0.30)$; plasma viscosity and white cell count $(0.26)$ and haematocrit $(r=0.21)$; haematocrit and white cell count $(\mathrm{r}=0.26)$; mean red cell volume and red cell count $(\mathrm{r}=-0.40)$; and white cell count and platelet count $(\mathrm{r}=0.22)$.

Table 2 summarises the relationships of rheological variables to continuous risk factors. Plasma and blood viscosity were positively related to triglyceride, cholesterol, VLDL and LDL levels; and inversely related to HDL cholesterol levels. Plasma and blood viscosity were also positively related to systolic and diastolic blood pressure. Fibrinogen, haematocrit and white cell count showed similar, but weaker, relationships to these risk factors, with the exception of HDL which was inversely related to fibrinogen and white cell count, and positively related to mean cell volume. Plasma viscosity and fibrinogen increased with age, while haematocrit and red cell count decreased slightly with age. Height was inversely associated with plasma viscosity, fibrinogen,

\begin{tabular}{|c|c|c|c|c|c|c|c|c|}
\hline VARIABLE & FIB & PV & BV & $\mathrm{HCT}$ & MCV & RCC & WCC & PC \\
\hline Age & 0.16 & 0.11 & & -0.06 & & -0.07 & & \\
\hline Height & -0.06 & -0.09 & & & & & -0.08 & -0.08 \\
\hline Weight & & & & & -0.06 & 0.08 & & -0.07 \\
\hline Body Mass Index & & & 0.05 & & -0.09 & 0.10 & & \\
\hline Systolic BP & 0.05 & 0.14 & 0.11 & 0.05 & & & 0.07 & \\
\hline Diastolic BP & & 0.09 & 0.11 & 0.08 & & 0.08 & & \\
\hline Cholesterol & & 0.21 & 0.15 & 0.06 & & & & 0.07 \\
\hline HDL & -0.19 & -0.11 & -0.12 & -0.08 & 0.10 & -0.14 & -0.23 & \\
\hline LDL & 0.08 & 0.14 & 0.10 & & & 0.05 & 0.06 & 0.08 \\
\hline Triglyceride (log) & 0.05 & 0.24 & 0.24 & 0.16 & 0.05 & 0.12 & 0.20 & \\
\hline VLDL & 0.07 & 0.22 & 0.19 & 0.12 & & 0.11 & 0.15 & \\
\hline
\end{tabular}

Table 2 Relationships of rheological variables to risk factors which are continuous variables. Data are given as Spearman rank correlation coefficients, where $p<0.05$. The abbreviations for rheological variables are given in Table 1 
Table 3 Relationships of rheological variables to risk factors which are categorical variables, and to baseline evidence of cardiovascular disease. Data are given as percentage of one SD increase in each rheological variable in the presence (relative to the absence) of each categorical variable, where $p<0.05$, $* \mathrm{p}<0.01, * * \mathrm{p}<0.001, * * * \mathrm{p}<0.0001$. The coefficient of variation of each rheological variable in the study population is also given. See text for interpretation
Table 4 Baseline levels [mean (SD)] of rheological variables by the three major outcomes of the WOSCOPS Study; and univariate hazard ratios $(95 \% \mathrm{CI})$ and probability values for the 3 major outcomes for event versus no event for approximate 1 SD increase in baseline level of variable

\begin{tabular}{lccccccc}
\hline VARIABLE & FIB & PV & BV & HCT & MCV & RCC & WCC \\
\cline { 2 - 7 } CV(\%) & 19.9 & 6.0 & 8.3 & 6.5 & 4.5 & 7.0 & 27.9 \\
Category & & & & & & & \\
Unemployed & $29 * * *$ & $28^{* * *}$ & $17^{* * *}$ & & $13^{* * *}$ & -6 & $24 * * *$ \\
Alcohol>20 units/week & $-23^{* * *}$ & 8 & $19^{* * *}$ & $18^{* * *}$ & $58^{* * *}$ & $-19^{* * *}$ & \\
Diabetes & $34^{*}$ & 25 & & & $-38^{*}$ & 29 & \\
Hypertension & $18^{* * *}$ & $30^{* * *}$ & $24^{* * *}$ & $11^{* *}$ & & & $11^{*}$ \\
Nitrate use & $46^{* * *}$ & $33^{* *}$ & 11 & & & & 29 \\
Abnormal ECG & $21^{* * *}$ & $28^{* * *}$ & $20^{* * *}$ & 9 & & $11^{*}$ & $16^{* *}$ \\
Angina & $30^{* * *}$ & $23^{* * *}$ & & & & & $23^{* *}$ \\
Claudication & $46^{* * *}$ & $58^{* * *}$ & $45^{* * *}$ & $20^{*}$ & $20^{*}$ & & $59^{* * *}$ \\
\hline
\end{tabular}

\begin{tabular}{|c|c|c|c|c|}
\hline & \multicolumn{2}{|c|}{ Non-fatal MI or definite CHD death } & \multirow{2}{*}{$\begin{array}{c}\text { CHD death } \\
(\mathrm{n}=102)\end{array}$} & \multirow{2}{*}{$\begin{array}{l}\text { All Death } \\
(\mathrm{n}=241)\end{array}$} \\
\hline & $\begin{array}{c}\text { No } \\
(\mathrm{n}=6173)\end{array}$ & $\begin{array}{c}\text { Yes } \\
(\mathrm{n}=422)\end{array}$ & & \\
\hline Fibrinogen $(g / L)$ & \multirow[t]{3}{*}{$4.28(0.86)$} & $4.51(0.91)$ & $4.63(0.94)$ & $4.58(0.95)$ \\
\hline hazard ratio & & $1.33(1.21,1.47)$ & $1.50(1.23,1.82)$ & $1.26,1.63$ \\
\hline $\mathbf{p}$ & & 0.0001 & 0.0001 & 0.0001 \\
\hline Plasma viscosity (mPa.s) & \multirow[t]{3}{*}{$1.33(0.08)$} & $1.35(0.08)$ & $1.36(0.08)$ & $1.35(0.08)$ \\
\hline hazard ratio & & $1.31(1.18,1.46)$ & $1.39(1.13,1.72)$ & $1.29(1.12,1.49)$ \\
\hline $\mathbf{p}$ & & 0.0001 & 0.002 & 0.0005 \\
\hline Blood viscosity (mPa.s) & \multirow{3}{*}{$3.38(0.28)$} & $3.46(0.29)$ & $3.46(0.26)$ & $3.45(0.30)$ \\
\hline hazard ratio & & $1.25(1.16,1.35)$ & $1.23(1.05,1.45)$ & $1.21(1.08,1.34)$ \\
\hline $\mathbf{p}$ & & 0.0001 & 0.012 & 0.0006 \\
\hline Haematocrit (\%) & \multirow[t]{3}{*}{$43.9(2.9)$} & $44.5(2.9)$ & $44.4(2.6)$ & $44.4(3.0)$ \\
\hline hazard ratio & & $1.22(1.11,1.35)$ & $1.16(0.95,1.41)$ & $1.17(1.03,1.33)$ \\
\hline $\mathbf{p}$ & & 0.0001 & 0.016 & 0.02 \\
\hline Mean red cell volume (fL) & \multirow[t]{3}{*}{$90.7(4.1)$} & $91.2(4.1)$ & $91.1(4.5)$ & $91.4(4.6)$ \\
\hline hazard ratio & & $1.12(1.02,1.22)$ & $1.06(0.88,1.28)$ & $1.14(1.01,1.29)$ \\
\hline $\mathbf{p}$ & & 0.021 & 0.55 & 0.03 \\
\hline Red cell count $\left(10^{12} / L\right)$ & \multirow[t]{3}{*}{$4.84(0.34)$} & $4.88(0.34)$ & $4.88(0.35)$ & $4.87(0.36)$ \\
\hline hazard ratio & & $1.12(1.02,1.22)$ & $1.11(0.92,1.33)$ & $1.06(0.94,1.20)$ \\
\hline $\mathbf{p}$ & & 0.021 & 0.30 & 0.37 \\
\hline White cell count $\left(10^{9} / \mathrm{L}\right)$ & \multirow[t]{3}{*}{$6.54(1.84)$} & $7.08(1.92)$ & $7.01(2.10)$ & $7.07(1.90)$ \\
\hline hazard ratio & & $1.32(1.21,1.45)$ & $1.27(1.05,1.54)$ & $1.31(1.16,1.48)$ \\
\hline $\mathbf{p}$ & & 0.0001 & 0.01 & 0.0001 \\
\hline Platelet count $\left(10^{9} / \mathrm{L}\right)$ & \multirow[t]{3}{*}{$282(65)$} & $282(67)$ & $283(75)$ & $286(71)$ \\
\hline hazard ratio & & $0.97(0.88,1.06)$ & $1.00(0.83,1.22)$ & $1.04(0.92,1.18)$ \\
\hline $\mathrm{p}$ & & 0.48 & 0.99 & 0.53 \\
\hline
\end{tabular}

Table 5 Multivariate hazard ratios $(95 \%$ CI) and p-values for three major outcomes by baseline levels of fibrinogen, plasma viscosity, blood viscosity, haematocrit, and white cell count, adjusted for a hierarchy of baseline covariates. (Firstly for age and treatment group; subsequently for smoking; lipids (HDL, LDL and VLDL cholesterol; $\log$ triglyceride); other risk factors; and CHD indicators; as defined in the methods section)

\begin{tabular}{|c|c|c|c|c|c|c|}
\hline $\begin{array}{l}\text { Variates considered } \\
\text { (approximate 1SD) }\end{array}$ & $\begin{array}{l}\text { Non-fatal MI/CHD } \\
\text { Death } \\
\text { RR[95\% CI] }\end{array}$ & p-value & $\begin{array}{l}\text { CHD Death } \\
\text { RR }[95 \% \text { CI }]\end{array}$ & p-value & $\begin{array}{l}\text { All Death } \\
\text { RR }[95 \% \mathrm{CI}]\end{array}$ & p-value \\
\hline $\begin{array}{l}\text { Fibrinogen }(1 \mathrm{~g} / \mathrm{L}) \\
\text { +Smoking } \\
\text { +Lipids } \\
\text { +Other risk factors } \\
\text { +CHD indicators }\end{array}$ & $\begin{array}{l}1.26(1.14,1.40) \\
1.18(1.06,1.31) \\
1.13(1.02,1.26) \\
1.12(1.00,1.25) \\
1.11(0.99,1.23)\end{array}$ & $\begin{array}{l}0.0001 \\
0.0029 \\
0.026 \\
0.048 \\
0.073\end{array}$ & $\begin{array}{l}1.37(1.13,1.67) \\
1.27(1.03,1.57) \\
1.27(1.03,1.57) \\
1.23(1.00,1.52) \\
1.18(0.95,1.46)\end{array}$ & $\begin{array}{l}0.0018 \\
0.023 \\
0.023 \\
0.052 \\
0.13\end{array}$ & $\begin{array}{l}1.32(1.16,1.51) \\
1.22(1.06,1.40) \\
1.22(1.06,1.40) \\
1.20(1.04,1.38) \\
1.18(1.02,1.36)\end{array}$ & $\begin{array}{l}0.0001 \\
0.0059 \\
0.0059 \\
0.012 \\
0.022\end{array}$ \\
\hline $\begin{array}{l}\text { Plasma viscosity (0.1 mPa.s) } \\
\text { +Smoking } \\
\text { +Lipids } \\
\text { +Other risk factors } \\
\text { +CHD indicators }\end{array}$ & $\begin{array}{l}1.25(1.12,1.40) \\
1.21(1.08,1.35) \\
1.17(1.04,1.31) \\
1.15(1.02,1.28) \\
1.14(1.02,1.28)\end{array}$ & $\begin{array}{l}0.0001 \\
0.0009 \\
0.0066 \\
0.019 \\
0.024\end{array}$ & $\begin{array}{l}1.29(1.04,1.61) \\
1.24(0.99,1.54) \\
1.24(0.99,1.54) \\
1.17(0.93,1.47) \\
1.15(0.91,1.44)\end{array}$ & $\begin{array}{l}0.020 \\
0.060 \\
0.060 \\
0.17 \\
0.25\end{array}$ & $\begin{array}{l}1.20(1.04,1.39) \\
1.14(0.98,1.32) \\
1.14(0.98,1.32) \\
1.09(0.94,1.27) \\
1.07(0.92,1.25)\end{array}$ & $\begin{array}{l}0.015 \\
0.085 \\
0.085 \\
0.27 \\
0.37\end{array}$ \\
\hline $\begin{array}{l}\text { Blood viscosity }(0.25 \text { mPa.s }) \\
\text { +Smoking } \\
\text { +Lipids } \\
\text { +Other risk factors } \\
\text { +CHD indicators }\end{array}$ & $\begin{array}{l}1.24(1.15,1.34) \\
1.18(1.09,1.28) \\
1.16(1.07,1.25) \\
1.13(1.04,1.23) \\
1.14(1.05,1.23)\end{array}$ & $\begin{array}{l}0.0001 \\
0.0001 \\
0.0005 \\
0.0030 \\
0.0025\end{array}$ & $\begin{array}{l}1.22(1.04,1.43) \\
1.14(0.97,1.35) \\
1.14(0.97,1.35) \\
1.09(0.93,1.29) \\
1.08(0.91,1.28)\end{array}$ & $\begin{array}{l}0.016 \\
0.11 \\
0.11 \\
0.30 \\
0.36\end{array}$ & $\begin{array}{l}1.19(1.07,1.32) \\
1.11(1.00,1.24) \\
1.11(1.00,1.24) \\
1.07(0.96,1.20) \\
1.07(0.96,1.19)\end{array}$ & $\begin{array}{l}0.0011 \\
0.056 \\
0.056 \\
0.20 \\
0.25\end{array}$ \\
\hline $\begin{array}{l}\text { Haematocrit ( } 3 \%) \\
\text { +Smoking } \\
\text { +Lipids } \\
\text { +Other risk factors } \\
\text { +CHD indicators }\end{array}$ & $\begin{array}{l}1.25(1.13,1.38) \\
1.17(1.06,1.29) \\
1.16(1.05,1.28) \\
1.13(1.03,1.25) \\
1.14(1.03,1.26)\end{array}$ & $\begin{array}{l}0.0001 \\
0.0021 \\
0.0038 \\
0.014 \\
0.0093\end{array}$ & $\begin{array}{l}1.19(0.98,1.45) \\
1.11(0.90,1.35) \\
1.11(0.90,1.35) \\
1.05(0.86,1.28) \\
1.06(0.87,1.30)\end{array}$ & $\begin{array}{l}0.078 \\
0.33 \\
0.33 \\
0.66 \\
0.58\end{array}$ & $\begin{array}{l}1.20(1.06,1.37) \\
1.10(0.97,1.26) \\
1.10(0.97,1.26) \\
1.08(0.94,1.23) \\
1.07(0.94,1.22)\end{array}$ & $\begin{array}{l}0.0046 \\
0.14 \\
0.14 \\
0.28 \\
0.30\end{array}$ \\
\hline $\begin{array}{l}\text { White cell count }\left(2 \times 10^{9} / \mathrm{L}\right) \\
\qquad \text { +Smoking } \\
\text { +Lipids } \\
\text { +Other risk factors } \\
\text { +CHD indicators }\end{array}$ & $\begin{array}{l}1.35(1.23,1.48) \\
1.22(1.09,1.35) \\
1.17(1.05,1.30) \\
1.15(1.03,1.28) \\
1.13(1.01,1.26)\end{array}$ & $\begin{array}{l}0.0001 \\
0.0003 \\
0.0061 \\
0.015 \\
0.027\end{array}$ & $\begin{array}{l}1.31(1.08,1.60) \\
1.14(0.91,1.42) \\
1.14(0.91,1.42) \\
1.08(0.86,1.34) \\
1.05(0.84,1.32)\end{array}$ & $\begin{array}{l}0.0063 \\
0.26 \\
0.26 \\
0.52 \\
0.68\end{array}$ & $\begin{array}{l}1.35(1.19,1.53) \\
1.15(1.00,1.33) \\
1.15(1.00,1.33) \\
1.11(0.96,1.28) \\
1.09(0.95,1.26)\end{array}$ & $\begin{array}{l}0.0001 \\
0.053 \\
0.053 \\
0.15 \\
0.23\end{array}$ \\
\hline
\end{tabular}




\begin{tabular}{|c|c|c|c|c|c|}
\hline & \multicolumn{2}{|c|}{ PLACEBO } & \multicolumn{2}{|c|}{ PRAVASTATIN } & \multirow{2}{*}{$\frac{\text { 2-sample }}{\underline{\text { t-test }}}$} \\
\hline & $\frac{\text { Baseline }}{(\mathrm{n}=3293)}$ & $\frac{1 \text { year }}{(n=2990)}$ & $\frac{\text { Baseline }}{(n=3302)}$ & $\underset{(n=3001)}{1 \text { vear }}$ & \\
\hline $\begin{array}{l}\text { LDL cholesterol } \\
(\mathrm{mmol} / \mathrm{L})\end{array}$ & $\begin{array}{c}4.97 \\
(0.45)\end{array}$ & $\begin{array}{c}4.86 \\
(0.68)\end{array}$ & $\begin{array}{c}4.96 \\
(0.45)\end{array}$ & $\begin{array}{c}3.72 \\
(0.84)\end{array}$ & 0.0001 \\
\hline $\begin{array}{l}\text { VLDL cholesterol } \\
(\mathrm{mmol} / \mathrm{L})\end{array}$ & $\begin{array}{c}0.86 \\
(0.38)\end{array}$ & $\begin{array}{c}0.91 \\
(0.48)\end{array}$ & $\begin{array}{c}0.86 \\
(0.40)\end{array}$ & $\begin{array}{c}0.77 \\
(0.39)\end{array}$ & 0.0001 \\
\hline $\begin{array}{l}\text { HDL cholesterol } \\
(\mathrm{mmol} / \mathrm{L})\end{array}$ & $\begin{array}{c}1.14 \\
(0.25)\end{array}$ & $\begin{array}{l}1.15 \\
(0.27)\end{array}$ & $\begin{array}{c}1.14 \\
(0.24)\end{array}$ & $\begin{array}{c}1.21 \\
(0.28)\end{array}$ & 0.0001 \\
\hline $\begin{array}{l}\text { Fibrinogen } \\
(\mathrm{g} / \mathrm{L})\end{array}$ & $\begin{array}{c}4.30 \\
(0.85)\end{array}$ & $\begin{array}{c}4.37 \\
(0.84)\end{array}$ & $\begin{array}{c}4.29 \\
(0.87)\end{array}$ & $\begin{array}{c}4.33 \\
(0.81)\end{array}$ & 0.09 \\
\hline $\begin{array}{l}\text { Plasma viscosity } \\
\text { (mPa.s) }\end{array}$ & $\begin{array}{c}1.330 \\
(0.079)\end{array}$ & $\begin{array}{c}1.324 \\
(0.080)\end{array}$ & $\begin{array}{c}1.329 \\
(0.082)\end{array}$ & $\begin{array}{c}1.309 \\
(0.079)\end{array}$ & 0.0001 \\
\hline $\begin{array}{l}\text { Blood viscosity } \\
\text { (mPa.s) }\end{array}$ & $\begin{array}{c}3.39 \\
(0.28)\end{array}$ & $\begin{array}{c}3.35 \\
(0.28)\end{array}$ & $\begin{array}{c}3.39 \\
(0.29)\end{array}$ & $\begin{array}{c}3.32 \\
(0.27)\end{array}$ & 0.0001 \\
\hline $\begin{array}{l}\text { Haematocrit } \\
(\%)\end{array}$ & $\begin{array}{l}43.9 \\
(2.9)\end{array}$ & $\begin{array}{l}43.6 \\
(2.9)\end{array}$ & $\begin{array}{l}43.9 \\
(3.0)\end{array}$ & $\begin{array}{l}43.6 \\
(2.8)\end{array}$ & 0.08 \\
\hline $\begin{array}{l}\text { Mean cell volume } \\
\text { (fL) }\end{array}$ & $\begin{array}{l}90.7 \\
(4.1)\end{array}$ & $\begin{array}{l}90.3 \\
(4.2)\end{array}$ & $\begin{array}{l}90.8 \\
(4.1)\end{array}$ & $\begin{array}{l}90.3 \\
(4.1)\end{array}$ & 0.04 \\
\hline $\begin{array}{l}\text { Red cell count } \\
\left(10^{12} / L\right)\end{array}$ & $\begin{array}{c}4.85 \\
(0.34)\end{array}$ & $\begin{array}{c}4.83 \\
(0.35)\end{array}$ & $\begin{array}{c}4.85 \\
(0.35)\end{array}$ & $\begin{array}{c}4.83 \\
(0.34)\end{array}$ & 0.30 \\
\hline $\begin{array}{l}\text { White cell count } \\
\left(10^{9} / \mathrm{L}\right)\end{array}$ & $\begin{array}{c}6.59 \\
(1.84)\end{array}$ & $\begin{array}{c}6.58 \\
(1.86)\end{array}$ & $\begin{array}{c}6.55 \\
(1.86)\end{array}$ & $\begin{array}{c}6.62 \\
(1.91)\end{array}$ & 0.12 \\
\hline
\end{tabular}

Table 6 Baseline and 1-year levels of lipoproteins and rheological variables by treatment group. Data are given as mean (SD) white cell count and platelet count; while weight and body mass index were positively related to red cell count and inversely related to mean cell volume.

Table 3 summarises the relationships of rheological variables to risk factors which are categorical variables (not employed, alcohol consumption greater than 20 units per week, history of diabetes or hypertension), as well as baseline evidence of cardiovascular disease (nitrate consumption, abnormal ECG, history of angina or claudication on Rose questionnaire). Data are expressed as the percentage of one standard deviation increase in each rheological variable in the presence of each categorical variable, where this increase is statistically significant at $p<0.05$. The standard deviation of each rheological variable is given in the first column of Table 1. For example, the mean increase in plasma fibrinogen in unemployed men compared to those in employment is $29 \%$ of one standard deviation, $=0.29 \times 0.86 \mathrm{~g} / \mathrm{L},=0.25 \mathrm{~g} / \mathrm{L}$. Expression of the data in this way allows comparison of the associations of categorical risk factors or measures of cardiovascular disease with rheological variables, whose coefficients of variations in the study population (also given in Table 3) differ widely, e.g. from $4.5 \%$ for MCV to $27.9 \%$ for white cell count. The only significant correlation of the platelet count (coefficient of variation 22.9\%) was a higher level in men with claudication compared to men without claudication $(294 \pm 67$ vs. $284 \pm 10^{9} / \mathrm{L} ; \mathrm{p}=0.039 ; 15 \%$ SD increase).

Table 4 shows that mean baseline levels of all rheological variables (except platelet count) were significantly higher in men who subsequently experienced the primary endpoint (non-fatal myocardial infarction or definite CHD death) compared to men who did not. This table also shows mean baseline levels in men who died from CHD (definite and suspect) and from all causes; and gives hazard ratios for these outcomes which were associated with approximately one standard deviation increase in each rheological variable on univariate analyses. The hazard ratios of the primary endpoint associated with increases in plasma viscosity of $0.1 \mathrm{mPa} . \mathrm{s}$, in fibrinogen of $1 \mathrm{~g} / \mathrm{L}$, and in white cell count of $2 \times 10^{9} / \mathrm{L}$ were each strong (1.31-1.33). The hazard ratio of the primary endpoint associated with increased blood viscosity was 1.25 , and for haematocrit was 1.22 , which in turn reflected the apparently equal increases in the hazard ratios of its two determinants: mean red cell volume and red cell count (both 1.12). The hazard ratios for CHD death and for all-cause death associated with rheological variables were generally similar to those for the primary endpoint, except that fibrinogen appeared a stronger predictor of both CHD death and total mortality (risk ratios 1.50 and 1.44 respectively) than of the primary endpoint.

Table 5 shows the effects of progressive adjustments in multivariate analyses for treatment group and age; CHD risk factors; and evidence of baseline CHD on the associations (hazard ratios) of baseline rheological variables with outcomes. Plasma and blood viscosity, haematocrit and white cell count remained significantly associated with the primary endpoint after all these adjustments: the most significant of these residual associations being blood viscosity [hazard ratio $1.14(1.05,1.23) ; \mathrm{p}=0.0025]$. The association of fibrinogen was reduced to borderline statistical significance $(p=0.073)$ after inclusion of multiple CHD indicators in the model; as was its association with CHD death. The associations of rheological variables with all-cause mortality became non-significant after inclusion of smoking: with the exception of fibrinogen which remained a significant association of all-cause mortality after all adjustments [hazard ratio $1.18(1.02,1.36)$; $\mathrm{p}=0.022]$.

Table 6 shows baseline and 1-year levels of lipoproteins and rheological factors by treatment group. There were no significant differences between treatment groups at baseline. Plasma viscosity fell by about one quarter of a standard deviation in the pravastatin group (mean change $-0.19 \mathrm{mPa} . \mathrm{s}, 95 \% \mathrm{CI}-0.022,-0.016$ ) and the mean plasma viscosity change over baseline at 1 year was significant ( $p<0.0001)$. Calculated blood viscosity also fell by about one quarter of a standard deviation in the pravastatin group (mean change $-0.062 \mathrm{mPa} . \mathrm{s}, 95 \% \mathrm{CI}-0.072$, -0.052 ) and again the between group change over baseline at 1 year was significant ( $\mathrm{p}<0.0001$ ). No significant effect of pravastatin on fibrinogen, haematocrit or white cell count was observed (Table 6). The fall in plasma viscosity appeared to be related more to the $25 \%$ reduction in 
LDL than to the $10 \%$ reduction in VLDL; changes over baseline for plasma viscosity in both treatment groups were related significantly to changes in LDL (Spearman $r=0.19$ ) but only marginally to changes in VLDL $(r=0.08)$. While changes in plasma viscosity were more strongly related to changes in fibrinogen $(r=0.30)$, the reduction in plasma viscosity in the pravastatin group was not attributable to reduction in fibrinogen.

\section{Discussion}

In this large study of hypercholesterolaemic men, we have first confirmed that rheological variables are associated with several major cardiovascular risk factors, as previously shown in some epidemiological and case-control studies $(5,7-11,21)$. These include correlations of baseline plasma and blood viscosity with cholesterol, triglyceride, LDL and VLDL ( $r=0.10-0.24)$. Second, we observed correlations of rheological variables with prevalent cardiovascular disease, which again are consistent with previous reports $(5,8,9,21)$.

Third, we confirmed the findings of four prospective epidemiological studies that plasma viscosity $(10,12,13,14,23)$ and whole blood viscosity in one study (13) are associated with incident CHD events. As in these epidemiological studies, the predictive value of plasma viscosity was due partly to plasma fibrinogen, which correlated with plasma viscosity (Spearman $r=0.47$ ) and which was also a predictor of CHD events, as in prospective epidemiological studies (22). The association of haematocrit with incident CHD events also confirms epidemiological studies (23) and appeared in the present study to reflect approximately equal contributions from its two determinants: mean red cell volume and red cell count (Table 4). The strength of these associations of rheological variables with incident $\mathrm{CHD}$ was similar to that of major CHD risk factors in the present study (2). For example, the hazard ratios of the primary endpoint associated with 1 SD increases in plasma viscosity, fibrinogen or white cell count (1.31-1.33) were similar to the hazard ratios for an increase of 5 years in age (1.35) or a $20 \mathrm{mmHg}$ increase in systolic blood pressure (1.29) previously reported in this study (2). On multivariate analyses of rheological variables including treatment group, CHD risk factors and evidence of baseline CHD, blood viscosity showed independent associations with CHD risk (Table 5). This finding suggests that increased blood viscosity may promote CHD, independently of the potentially confounding effects of CHD risk factors and of detectable baseline CHD. The associations of fibrinogen and white cell count with incident CHD may, of course, reflect a possible role of inflammatory markers in CHD (22), as well as their rheological effects (23). The independent association of fibrinogen with total mortality in this study was also observed in the Scottish Heart Health Study (24).

Finally, we have shown that pravastatin treatment lowered plasma and blood viscosity significantly after 1 year. This was partly attributable to reduction in plasma LDL (which fell by $25 \%$ on pravastatin treatment) and partly to reduction in VLDL (which fell by 10\%). These findings are consistent with the report of a small, short-term study of pravastatin (25) and with clinical and epidemiological studies relating LDL, VLDL or total cholesterol to plasma or blood viscosity $(5,7-12)$. It is possible that part of pravastatin's effect on viscosity results from a non-lipid mechanism of action (26). The reduction in plasma viscosity during pravastatin therapy was not related to change in plasma fibrinogen, which increased slightly in both pravastatin and control groups, possibly simply due to ageing (5). While smoking affects fibrinogen and viscosity (Table 1), there was no significant change in smoking habit between treatment groups (data not shown). While a previous small study reported a reduction in plasma fibrinogen during pravastatin therapy (25), other, larger studies of pravastatin have generally not shown any change in fibrinogen $(27,28)$.

Whether or not the results of the current study are specific for pravastatin, or apply to other interventions which lower plasma lipoproteins, is not established. Variable effects of other statins, fibrates and other lipid-lowering interventions on viscosity and fibrinogen have been reported, in studies which are much smaller, and of shorter duration, than the present study $(5,27,28)$. The net effects of these other drugs on viscosity will presumably depend on their various effects on different lipoproteins, fibrinogen, and other plasma proteins with rheological effects $(5,27,28)$. Further large, randomised trials are required to establish the rheological effects of other lipid-lowering agents.

While the magnitude of the reductions in plasma and blood viscosity by pravastatin may appear small (due to the SI units used), they correspond to approximately one quarter of a standard deviation for the study population, and also correspond to the mean differences between men who experienced the primary outcome and men who did not (Table 4). The plasma viscosity reduction on pravastatin treatment is also consistent with decreases in risk ratios for study outcomes of 6-8\% (Table 4), and with similar decreases in CHD risk in other prospective studies of plasma viscosity (23). It is therefore plausible that viscosity reduction may account for about one-quarter of the CHD risk reduction by pravastatin; while the remaining risk reduction may reflect other mechanisms including effects on coronary artery plaques, endothelial function and thrombotic tendency $(3,4,6,28)$. We suggest that the early (1 year) reduction in viscosity on pravastatin treatment may be one plausible mechanism for the early (1 year) reduction in CHD events in WOSCOPS (1) and possibly in other statin studies (6). However, this hypothesis remains to be proven, because at present there are no large interventional studies showing that viscosity reduction lowers the risk of cardiovascular events (23). Because the reduction in LDL cholesterol in the pravastatin group of the present study was established after one year and was stable for the subsequent four years (1) it is possible that the reduction in viscosity at one year was maintained throughout the five years of the study. However, further long-term studies of pravastatin and viscosity are required to confirm this, and are currently in progress.

Increases in plasma viscosity in the general population increase the risk of prevalent, symptomatic peripheral ischaemia (claudication) in the presence of a given degree of atherosclerotic arterial narrowing: conversely viscosity reduction (e.g. by exercise) reduces ischaemic risk (21). Viscosity reduction by chronic urokinase therapy also reduces myocardial ischaemia in the presence of coronary artery disease (29). It therefore seems biologically plausible to suggest that LDL and VLDL reduction by pravastatin may partly reduce the risk of CHD events through reduction in plasma and blood viscosity. In the longer term, blood viscosity reduction by pravastatin might also reduce atherogenesis: we have recently shown that viscosity was an independent predictor of carotid arterial disease in a prospective study (30). Further viscosity reduction might be achieved by reducing plasma fibrinogen, a major risk predictor for $\mathrm{CHD}$ (22), which was an independent predictor of mortality in the present study. Plasma fibrinogen can be reduced by cessation of smoking, regular exercise, by certain fibrate drugs, or by ticlopidine $(5,31)$. We suggest that measurement of plasma viscosity and fibrinogen in future trials of lipoprotein reduction may help to elucidate the mechanisms for reduction in CHD risk. However, whether or not viscosity reduction lowers CHD risk remains to be proven in future trials. 


\section{Acknowledgements}

We thank Dr. A J Lee for information from the Scottish Heart Health Study/ Glasgow MONICA study; and Susan Lennie, Pamela McColl and Karen McLaughlin for technical assistance. The study was supported by a research grant from Bristol-Myers Squibb, Princeton, New Jersey.

\section{References}

1. Shepherd J, Cobbe SM, Ford I et al. Prevention of coronary heart disease with pravastatin in men with hypercholesterolaemia. N Engl J Med 1995; 333: $1301-7$

2. West of Scotland Coronary Prevention Study Group. Baseline risk factors and their association with outcome in the West of Scotland Coronary Prevention Study. Am J Cardiol 1997; 79: 750-62.

3. Levine GN, Keaney JF, Jr, Vita JA. Cholesterol reduction in cardiovascular disease. Clinical benefits and possible mechanisms. N Engl J Med 1995; 332: 512-21.

4. Treasure CB, Kline JL, Weintraub WS et al. Beneficial effects of cholesterol-lowering therapy on the coronary endothelium in patients with coronary artery disease. N Engl J Med 1995; 332: 481-7.

5. Lowe GDO. Blood rheology and vascular disease. In: Bloom AL, Forbes CD, Thomas DP, Tuddenham EGD (eds): Haemostasis and Thrombosis, $3^{\text {rd }}$ edn. Edinburgh: Churchill Livingstone 1994: 1169-88.

6. Vaughan CJ, Murphy MB, Buckley BM. Statins do more than just lower cholesterol. Lancet 1996; 348: 1079-82.

7. Lowe GDO, McArdle BM, Stromberg P et al. Increased blood viscosity and fibrinolytic inhibitor in type II hyperlipoproteinaemia. Lancet 1982; i: 472-5.

8. Lowe GDO, Smith WCS, Tunstall-Pedoe $\mathrm{H}$ et al. Cardiovascular risk and haemorheology: results from the Scottish Heart Health Study and the MONICA-Project, Glasgow. Clin Hemorheol 1988; 8: 518-24.

9. Lowe GDO, Wood DA, Douglas JT et al. Relationships of plasma viscosity, coagulation and fibrinolysis to coronary risk factors and angina. Thromb Haemost 1991; 65: 339-43.

10. Yarnell JWG, Baker IA, Sweetnam PM et al. Fibrinogen, viscosity and white blood cell count are major risk factors for ischemic heart disease. The Caerphilly and Speedwell Collaborative Heart Disease Studies. Circulation 1991; 83: 836-44.

11. Koenig W, Sund M, Ernst E, Mraz W, Hombach V, Keil U. Association between rheology and components of lipoproteins in human blood. Circulation 1992; 85: 2197-204.

12. Sweetnam PM, Thomas HF, Yarnell JWG, Beswick AD, Baker ID, Elwood PC. Fibrinogen, viscosity and the 10-year incidence of ischaemic heart disease. The Caerphilly and Speedwell Studies. Europ Heart J 1996, 17: 1814-20.

13. Lowe GDO, Lee AJ, Rumley A, Price JF, Fowkes FGR. Blood viscosity and risk of cardiovascular events: the Edinburgh Artery Study. Br J Haematol 1997; 96: 168-73.

14. Koenig W, Sund M, Filipiak B, Doring A, Lowel H, Ernst E. Plasma viscosity and the risk of coronary heart disease: results from the MONICAAugsburg cohort study, 1984 to 1992. Arterioscler Thromb Vasc Biol 1998; 18: 768-72.
15. West of Scotland Coronary Prevention Study Group. A coronary primary prevention study of Scottish men age 45-64 years: trial design. J Clin Epidemiol 1992; 45: 849-60.

16. West of Scotland Coronary Prevention Study Group. Screening experience and baseline characteristics in the West of Scotland Coronary Prevention Study. Am J Cardiol 1995; 76: 485-91.

17. Thorpe JM, Horstall GB, Stone MC. A new red-sensitive micronephelometer. Med Bio Eng 1967; 5: 51-6.

18. Stone MC, Thorpe JM. Plasma fibrinogen: a major coronary risk factor. J Roy Coll Gen Pract 1985; 35: 565-9.

19. Whittington RB, Harkness J. Whole-blood viscosity, as determined by plasma viscosity, hematocrit, and shear. Biorheology 1982; 19: 175-84.

20. Collett D. Modelling survival data in medical research. London: Chapman and Hall, 1994.

21. Lowe GDO, Fowkes FGR, Dawes J et al. Blood viscosity, fibrinogen and activation of coagulation and leukocytes in peripheral arterial disease and the normal population in the Edinburgh Artery Study. Circulation 1993; 87: 1915-20.

22. Danesh J, Collins R, Appleby P, Peto R. Fibrinogen, C-reactive protein, albumin or white cell count: meta-analyses of prospective studies of coronary heart disease. JAMA 1998; 279: 1477-82.

23. Danesh J, Collins R, Peto R, Lowe GDO. Haematocrit, viscosity, erythrocyte sedimentation rate: meta-analyses of prospective studies of coronary heart disease. Europ Heart J 2000; 21: 515-20.

24. Woodward M, Lowe GDO, Rumley A, Tunstall-Pedoe H. Fibrinogen as a risk factor for coronary heart disease and mortality in middle aged men and women - The Scottish Heart Health Study. Europ Heart J 1998; 19: 55-62.

25. Jay RH, Rampling MW, Betteridge DJ. Abnormalities of blood rheology in familial hypercholesterolaemia: effects of treatment. Atherosclerosis 1990; 85: $249-56$.

26. WOSCOPS Group. Influence of pravastatin and plasma lipids on clinical events in WOSCOPS. Circulation 1998; 97: 1440-5.

27. Branchi A, Rovellini A, Sommariva D, Gugliandolo C, Fasoli A. Effect of three fibrate derivatives and two HMG - CoA reductase inhibitors on plasma fibrinogen level in patients with primary hypercholesterolaemia. Thromb Haemost 1993; 70: 241-3.

28. Rosenson RS, Tangrey CC. Anti-atherothrombotic properties of statins. Implications for cardiovascular event reduction. JAMA 1998; 279: $1643-50$

29. Leschke M, Höffken H, Motz W, Blanke H, Schöbel F, Strauer BE. Chronisch-intermittierende Urokinasetherapie bei therapierefraktäner Angina pectoris. Dtsch med Wschr 1992; 117: 81.

30. Lee AJ, Mowbray PI, Lowe GDO, Rumley A, Fowkes FGR, Allan PL. Blood viscosity and elevated carotid intima-media thickness in men and women: the Edinburgh Artery Study. Circulation 1998; 97: 1467-73.

31. Cortellaro M, Cofrancesco E, Boschetti C, Cortellaro F, Mancini M, Mariani M, Paoletti R. Effects of fluvastatin and bezafibrate combination on plasma fibrinogen, t-plasminogen activator inhibitor and C-reactive protein levels in coronary artery disease patients with mixed hyperlipidaemia (FACT Study). Thromb Haemost 2000; 83: 549-54.

Received February 22, 2000 Accepted after resubmission April 21, 2000 